\title{
RANCANG BANGUN TEKNOLOGI TEPAT GUNA UNTUK MEMBANTU MENINGKATKAN PRODUKTIVITAS INDUSTRI KECIL (HOME INDUSTRY)
}

\author{
D e w a n t o \\ Jurusan Teknik Mesin/S1 Pendidikan Teknik Mesin, Universitas Negeri Surabaya \\ dewanto@unesa.ac.id
}

\begin{abstract}
Abstrak--Tujuan kegiatan ini adalah untuk meningkatkan produktivitas industri kecil penghasil bawang goreng. Industri kecil tersebut merupakan salah satu dari 20 tenant binaan tim pelaksana Program Pengembangan Kewirausahaan (PPK) Unesa yang sebagian besar didanai oleh Direktorat Riset dan Pengabdian kepada Masyarat (DRPM) tahun 2019. Metode yang digunakan dalam kegiatan ini adalah dengan melakukan rancang bangun Teknologi Tepat Guna (TTG) Mesin Perajang Bawang untuk menggantikan alat perajang bawang manual milik tenant yang penggunaanya sudah tidak efektif dan efisien lagi. Dari pelaksanaan program dihasilkan TTG Mesin Perajang bawang dengan spesifikasi: Kerangka baja ST.37, tinggi TTG $95 \mathrm{~cm}$, berat $14,8 \mathrm{~kg}$, motor $1 / 2$ PK, dan kapasitas TTG $1,2 \mathrm{~kg}$ bawang irisan per menit. Bila dibanding dengan peralatan tenant sebelumnya yang hanya berkapasitas $0,28 \mathrm{~kg}$ bawang irisan per menit, maka jelas dengan menerpkan TTG hasil rancangan tim pelaksana program PPK ini dapat meningkatkan produktivitas tenant.
\end{abstract}

Kata kunci: Industri kecil, produktivitas, dan Teknologi Tepat Guna

Abstract - The purpose of this activity is to increase the productivity of small onion producers producing fried onions. This small industry is one of the 20 tenants fostered by the Unesa Entrepreneurship Development Program (EDP) implementation team, which was largely funded by the Directorate of Research and Community Service (DRCS) in 2019. The method used in this activity is to design Appropriate Technology (AT) Onion Chopper Machine to replace the tenant manual onion chopper tool whose use is no longer effective and efficient. From the implementation of the program produced AT onion Chopper Machine with specifications: ST.37 steel frame, AT 95 $\mathrm{Cm}$ height, weight $14.8 \mathrm{~kg}, 1 / 2 \mathrm{PK}$ motor, and AT capacity of $1.2 \mathrm{~kg}$ sliced onions per minute. When compared with the previous tenant equipment which only has a capacity of $0.28 \mathrm{~kg}$ of sliced onions per minute, it is clear that by applying the AT designed by the EDP program implementation team, it can increase tenant productivity.

Keywords: Small industry, productivity, and Appropriate Technology

\section{PENDAHULUAN}

Sukomoro merupakan salah satu desa yang berada di Kabupaten Nganjuk, Propinsi Jawa Timur. Sebagian besar penduduknya memiliki mata pencaharian sebagai petani bawang merah. Oleh sebab itu wilayah ini dikenal sebagai sentra penghasil bawang merah.

Alfiatun adalah seorang penduduk Sukomoro (alumni Unesa) yang selain sebagai petani bawang merah juga sebagai pemilik industri kecil (pengrajin). Produk yang dihasilkan dari industri milik Alfiatun ini adalah bawang merah goreng. Dengan 3 orang tenaga kerjanya Alfiatun dapat memproduksi $17,5 \mathrm{~kg}$ bawang merah goreng tiap harinya. Tiap kg bawang merah goreng dijual dengan harga Rp.17.500,-. Industri kecil mitra (IKM) milik Alfiatun inilah yang menjadi tenant dalam pelaksanaan Program Pengembangan Kewirausahaan (PPK) ini.

Berdasarkan informasi dan hasil survai lapangan, bawang merah goreng hasil produksi IKM kualitasnya memang paling bagus dibanding bawang goreng hasil produksi industri kecil lainnya yang berada di sekitarnya. Hal ini disebabkan karena proses penggorengannya dilakukan dengan teknik khusus dan menggunakan minyak pilihan sehingga rasannya khas. Oleh sebab itu bawang goreng produk IKM ini selalu diburu oleh para pelanggan atau mitra usahanya seperti tukang bakso, penjual bakmi, penjual nasi goreng dan sebagainya yang berasal dari daerah Sukomoro, Kediri, Kertosono dan Madiun. Bahkan ada pedagang dari Surabaya yang memesan bawang merah goreng produk IKM ini $50 \mathrm{~kg}$ tiap harinya. Namun karena keterbatasan peralatan yang dimiliki, IKM belum mampu memenuhi semua order tersebut.

Peralatan yang digunakan IKM untuk memproduksi bawang goreng ternyata cukup sederhana, antara lain pisau, ember/waskom plastik, wajan penggoreng, kompor gas, dan lain-lainnya yang semuanya masih manual. Proses produksinya juga sangat sederhana yakni: bawang merah dikupas, dirajang/diiris-iris dengan pisau, kemudian baru digoreng. Sebagai konsekuensi dari penggunaan peralatan sederhana tersebut timbul permasalah yang menyebabkan produktivitas IKM rendah. Permasalahan tersebut adalah: 
(1) Proses perajangan bawang disamping membutuhkan waktu yang cukup lama dan melelahkan, juga membosankan pekerjanya, karena pekerjaannya monoton, dan tidak efisien.

(2) Hasil rajangan bawangnya kurang bisa stabil/seragam, karena mengandalkan kemampuan tangan, sehingga ada yang terlalu tipis, sedang, dan ada yang terlalu tebal (kurang efektif).

(3) Jika terlena (ngantuk) tangan pekerjanya sering teriris pisau
(4) Seringkali IKM dengan terpaksa harus mengecewakan pelanggan yang mau membeli bawang goreng hasil produksinya karena telah kehabisan.

Dalam upayanya untuk mengatasi permasalahan di atas sebenarnya IKM telah berupaya menghubungi Deprind, dan Pemkot Nganjuk. Namun hingga survai ini dilakukan belum mendapatkan solusi. Akhirnya karena ordernya semakin banyak IKM mengambil inisiatif dengan membeli 4 (empat) alat perajang bawang manual yang ditawarkan oleh seseorang kepadanya. Gambar alat tersebut adalah seperti berikut:

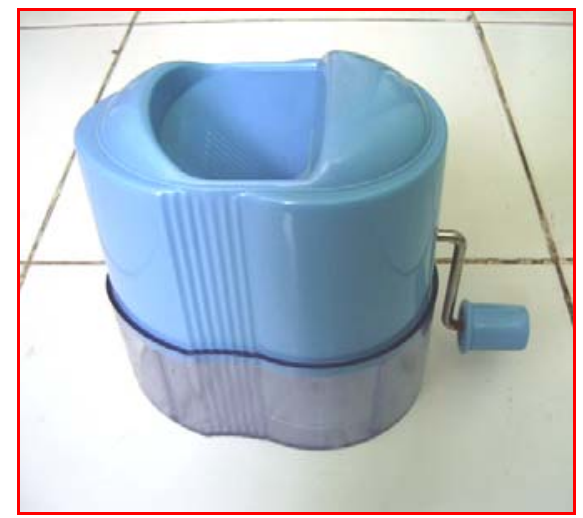

Gambar 1. Alat Perajang Bawang Manual

Mengetahui permasalahan di atas tim pelaksana PPK ingin mencoba membantu mengatasi permasalahan yang dihadapi industri kecil tersebut melalui kegiatan rancang bangun Teknologi tepat Guna (TTG). Melalui kegiatan ini diharapkan akan dapat dihasilkan sebuah TTG mesin perajang bawang yang kapasitasnya jauh lebih tinggi sehingga dapat digunakan untuk meningkatkan produktivitas IKM.

Dari latar belakang masalah di atas dapat diketahui bahwa:

1. Peralatan produksinya (terutama alat perajang bawang) masih menggunakan peralatan (manual), sehingga membutuhkan waktu lama untuk melakukan proses produksi (tidak efisien).

2. Karena peralatan produksinya masih manual, maka kapasitas produksinya sangat terbatas (hanya $17,5 \mathrm{~kg} / \mathrm{hari}$ ) sehingga tidak mampu memenuhi semua order pelanggannya yang sudah mencapai $50 \mathrm{~kg} / \mathrm{hari}$.

3. Karena penggunaan peralatan produksi yang manual ini pula IKM seringkali terpaksa harus mengecewakan pelanggan karena tidak dapat memenuhi order tepat pada waktunya.

Oleh karena itu, untuk dapat mengatasi permasalahan tersebut maka perlu sesegera mungkin dirancang dan dibuatkan alat yang dapat digunakan untuk melakukan proses perajangan bawang merah secara cepat, efektif dan efisien sehingga dapat digunakan IKM untuk meningkatkan produktivitasnya

\section{TUJUAN}

Tujuan kegiatan ini adalah untuk membantu masyarakat khususnya IKM dalam upaya mengatasi permasalahan yang dihadapi. Secara rinci tujuan tersebut dapat dijelaskan seperti berikut:

1. Untuk meningkatkan kapasitas produksi IKM minimal 5 kali dari kapasitas produksi sebelumnya agar dapat digunakan untuk meningkatkan penghasilannya, memenuhi order-order konsumennya, dan mengembangkan usahanya.

2. Meningkatkan efisiensi dan efektifitas (produktivitas) IKM melalui rancang bangun dan penerapan TTG mesin perajang bawang.

Perkembangan jumlah industri kecil dan menengah di Jawa Timur sangat menggembirakan, terutama setelah adanya krisis ekonomi. Saat ini jumlah usaha kecil dan menengah mencapai 6,6 juta, 2 (dua) juta dari tahun sebelumnya yang hanya berjumlah 4,6 juta. Industri keci dan mengah tersebut tersebar di berbagai wilayah Jawa Timur, dan kondisinya masih sangat membutuhkan adanya pembinaan yang intensif, terutama untuk meningkatkan produktivitasnya (Sutiono, 2002).

Berkaitan dengan produktivitas industri, I Nyoman Sutantra (2002), mengatakan bahwa suatu industri baru bisa dikatakan produktif jika industri tersebut dapat dilaksanakan secara efisien dan efektif, atau dapat menggunakan sumber daya yang seminimal mungkin dengan hasil yang seakurat mungkin. Dari pernyataan tersebut dapat diartikan bahwa bila ingin meningkatkan produktivitas suatau industri, maka dapat dilakukan dengan cara meningkatkan efisiensi dan efektivitas industri tersebut.

Menurut Haryono dkk. (1999), ada beberapa cara yang dapat ditempuh oleh pengusaha untuk meningkatkan efisiensi 
dan efektivitas usahanya. Antara lain: 1) Dengan meningkatkan skill atau keterampilan karyawannya, dan 2) Dengan memutakhirkan peralatan produksinya. Jika melihat kenyataan di lapangan, cara yang disebut terakhir ini jarang ditempuh oleh pengusaha kecil. Hal ini disamping disebabkan karena keterbatasan modal, juga karena keterbatasan pengetahuannya yang pada umumnya belum bisa mengakses informasi-informasi terkini khususnya yang berhubungan dengan perkembangan peralatan produksi yang semakin cepat canggih. Lain halnya dengan cara yang biasa ditempuh oleh pengusaha-pengusaha yang sudah besar (profesional), mereka rata-rata lebih suka memilih cara untuk memutakhirkan peralatan produksinya guna meningkatkan efisiensi dan efektifitas usahanya (John E.Biegel, 1998).

Terlepas dari golongan pengusaha besar atau pengusaha kecil, maka sebelum menentukan langkah/cara yang akan ditempuh untuk meningkatkan efisiensi dan efektivitas usahanya, pengusaha harus benar-benar mempertimbangkan dahulu cara yang akan ditempuh itu agar tidak justru malah merugi.

Industri kecil yang dipakai sebagai obyek dalam penelitian ini adalah industri kecil yang memiliki problem relevan seperti diutarakan di atas, yakni ingin meningkatkan efisiensi dan efektivitas (produktivitas) usahanya. Pimpinan industri juga menyadari bahwa hal ini dapat dilakukan dengan memutakhirkan peralatannya. Tetapi karena secara finansial belum mampu, serta pengetahuannya dalam bidang perkembangan peralatan produksi juga lemah, dan tidak punya inovasi untuk mengembangkan peralatannya, maka perlu dicari sulusi yang tepat untuk membantu memecahkannya.

Ahmadi (2001), menyatakan bahwa pada umumnya masalah produksi yang dihadapi oleh industri kecil dan menengah di Indonesia tidak cocok bila dipecahkan melalui penerapan/penggunaan mesin-mesin yang berteknologi mutakhir/canggih, tetapi justru banyak yang lebih cocok dipecahkan melalui penerapan teknologi tepat guna (TTG). Sebab biaya investasi untuk penerapan TTG relatif murah dan umumnya dapat terjangkau. Disamping itu pengoperasian dan perawatannya tidak membutuhkan penguasaan ilmu pengetahuan dan pengetahuan teknologi yang terlalu tinggi. Oleh karena itu, merupakan tindakan yang tepat dan solutif sekali bila penelitian ini berusaha merancang dan mewujudkan (TTG) untuk membantu mengatasi permasalahan yang dihadapi IKM (meningkatkan produktivitasnya).

\section{METODE}

Metode yang digunakan dalam penelitian ini adalah dengan melakukan rancang bangun Teknologi Tepat Guna (TTG) Mesin Perajang Bawang untuk menggantikan fungsi alat perajang bawang manual yang selama ini digunakan industri.

Secara berturut-turut perancangan TTG ini diawali dengan perancangan konsep dengan menggunakan gambar sket, piringan pemotong, jarak masing masing pisau pada piringan pemotong, posisi pisau pada saat pemotongan, sudut kemiringan pisau, jarak piringan pisau dengan corong/curah masuk, panjang pisau, dan posisi sertalebar curah masuk.

Setelah semua komponen dirancang maka langkah selanjutnya adalah pembuatan TTG sesuai dengan hasil rancangan, kemudian diujicoba dan dianalisis, serta dilakukan perbaikan sesuai dengan unjuk kerja TTG yang diinginkan.

\section{Perancangan konsep.}

Secara konsep TTG mesin perajang bawang dirancang dengan menggunakan beberapa komponen seperti pisau, piringan tempat pisau, Corong/curah masuk, V-belt, puly, dan motor listrik $1 / 2$ HP sebagai penggeraknya. Konsep tersebut disajikan seperti gambar berikut:
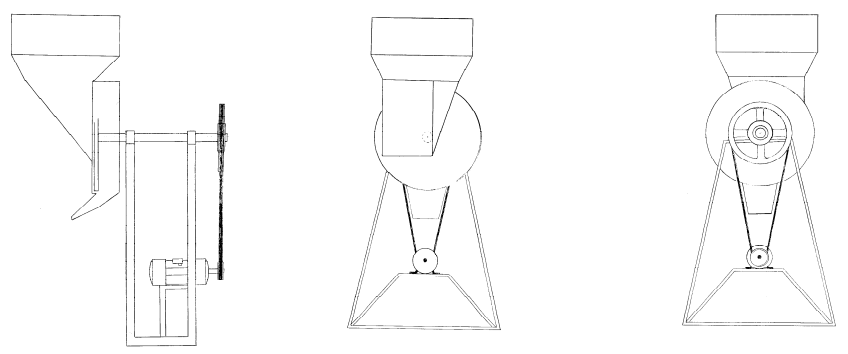

Tampak depan Tampak samping kiri Tampak samping kanan

\section{Perancangan piringan pemotong}

Bentuk dan dimensi piringan pemotong pada mesin ini sangat berpengaruh terhadap kualitas hasil rajangan bawang. Pada piringan ini pisau perajang harus diletakkan sedemikian rupa sehingga pada saat diputar untuk melakukan proses perajangan harus dapat menghasilkan rajangan bawang yang sempurna (sesuai standar). Oleh karena itu jumlah dan jarak peletakan pisau pada piringan ini harus dipilih dan diatur secara cermat.

Dengan mencermati teknologi alat perajang bawang yang ada sebelumnya, jumlah dan posisi pisau dapat diletakkan dengan tiga cara yakni: 


\section{a. Tiga pisau dengan jarak pisau $120^{\circ}$ seperti gambar berikut:}

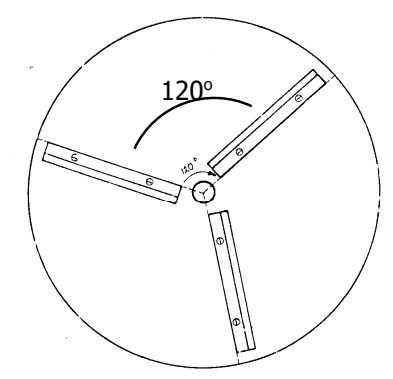

Gambar 3. Piringan dengan jarak pisau $120^{\circ}$

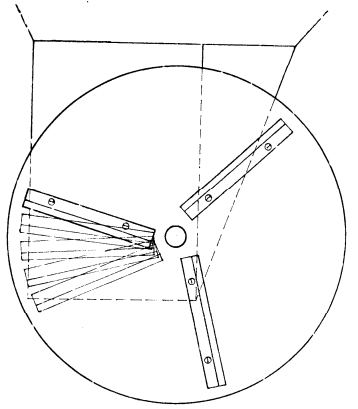

Gambar 4. Posisi pisau pada saat pemotongan

\section{b. Tiga pisau dengan jarak pisau $120^{\circ}+10^{\circ}$ seperti gambar} berikut:

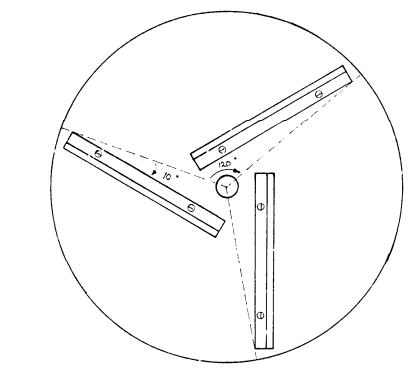

Gambar 5. Piringan dengan jarak pisau $120^{\circ}+10^{\circ}$

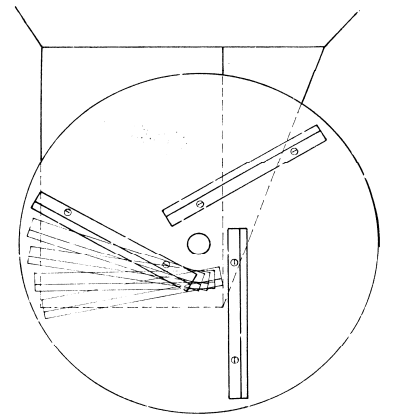

Gambar 6. Posisi pisau pada saat pemotongan

\section{c. Tiga pisau dengan jarak pisau $120^{\circ}+15^{\circ}$}

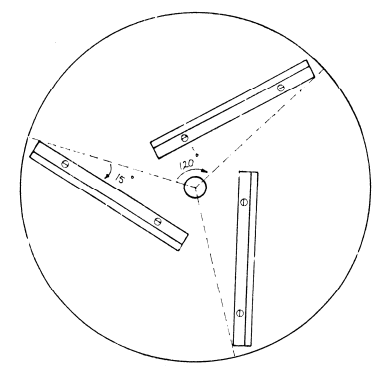

Gambar 7. Posisi pisau pada saat pemotongan

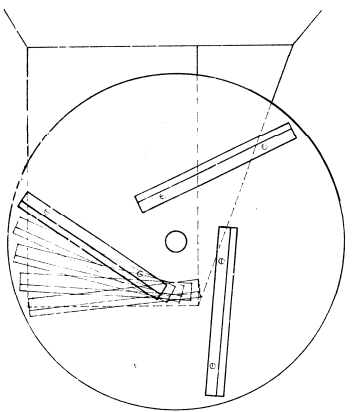

Gambar 8. Posisi pisau pada saat pemotongan
Dengan mencermati ketiga gambar posisi pisau pada saat pemotongan, maka yang paling tepat untuk diterapkan pada rancangan ini adalah posisi yang terakhir yakni dengan jarak pisau $120^{\circ}+15^{\circ}$. Sebab pada posisi ini pada saat pemotongan pisau tegak lurus dengan corong curah masuk sehingga akan menghasilkan rajangan bawang yang seragam. Keuntungan lain dari pemilihan posisi ini adalah bahwa pisau dapat dibuat dengan ukuran yang lebih panjang sehingga area perajangan lebih luas dan proses perajangan lebih cepat.

\section{Perancangan Sudut Kemiringan Pisau}

Pengaturan sudut kemiringan pisau akan berpengaruh terhadap tebal tipisnya hasil rajangan bawang. Semakin besar sudut kemiringan pisau maka akan semakin tebal hasil 
rajangan bawangnya. Demikian sebaliknya semakin kecil sudut kemiringan pisau akan semakin tipis pula hasil rajangan bawangnya. Oleh karena itu sudut kemiringan pisau akan dibuat sebesar $5^{\circ}$ dan akan dibuat konstruksinya sedemikian rupa sehingga akan mudah diatur dengan sesuai dengan ketebalan yang diinginkan. Jika digambarkan maka sudut kemiringan pisau dapat dilihat seperti gambar berikut:

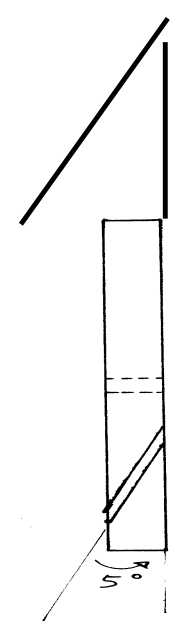

Gambar 9. Sudut Kemiringan Pisau

4. Perancangan Jarak Piringan pisau dengan Corong/Curah

\section{Masuk, dan panjang pisau}

Untuk memperoleh hasil rajangan yang seragam dan optimal maka jarak piringan dengan corong curah akan dibuat 1 - $2 \mathrm{~mm}$ (Gambar 10), sedangkan panjang pisau akan dibuat semaksimal mungkin yakni $1 / 2$ diameter piringan pemotong (Gambar

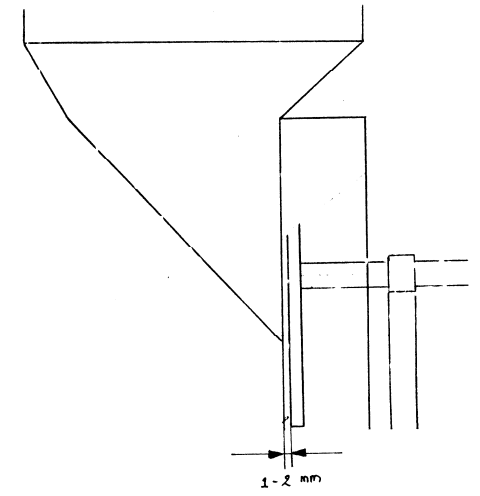

Gambar 10. Jarak corong dengan piringan

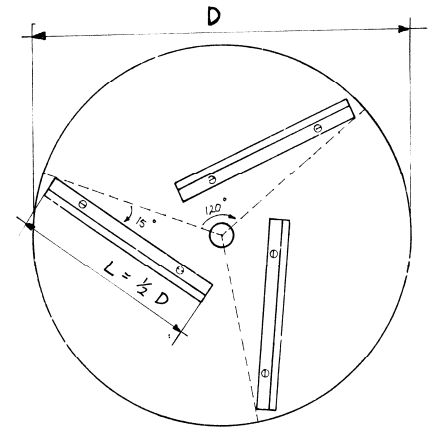

Gambar 11. Panjang pisau perajang

\section{Perancangan Posisi dan lebar corong/curah Masuk}

Agar diperoleh area pemotongan yang lebih luas maka posisi corong akan diupayakan lebih rendah $5 \mathrm{~cm}$ dari poros (h), dan lebar corong curah masuk akan dibuat $1 / 2$ dari diameter piringan seperti gambar berikut: 


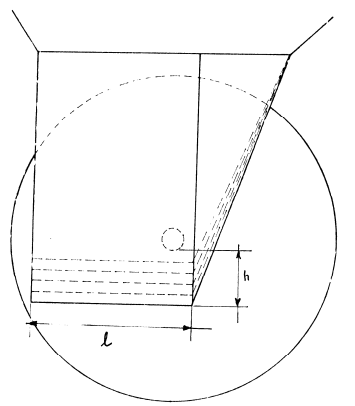

\section{HASIL DAN DISKUSI}

TTG Mesin perajang bawang hasil rancangan peneliti sebagaimana disajikan di atas selanjutnya dibuat di labortorium Fabrikasi dan Mesin Perkakas Teknik Mesin Fakultas Teknik Universitas Negeri Surabaya. Dengan menggunakan peralatan Las listrik, Gergaji, Gerinda tangan, mesin bubut, dan lain-lainnya berhasil diwujudkan TTG Mesin Perajang bawang seperti gambar berikut.

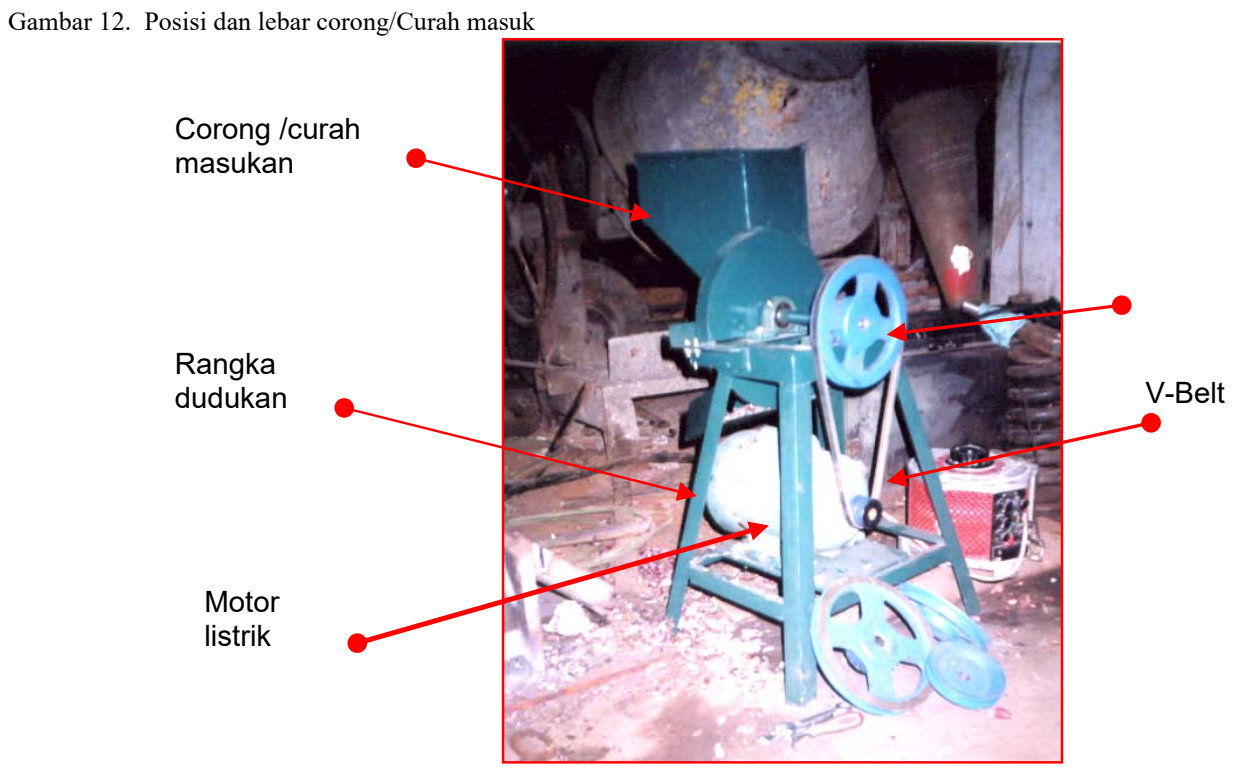

Gambar 13. TTG Mesin Perajang Bawang Hasil

Rancangan Bangun

Untuk mengetahui sejauh mana unjuk kerja TTG Mesin perajang bawang yang telah diwujudkan, maka TTG ini di tes atau diuji coba dengan berbagai variasi kecepatan motor dan pengaturan pisau. Fariasi kecepatan motor dites dengan menggunakan tachometer. Sedang untuk mengatur ketebalan hasil rajangan dilakukan melalui pengaturan posisi pisau. Berikut adalah gambar proses ujicoba dan tabel hasil pengujian yang telah dilakukan:
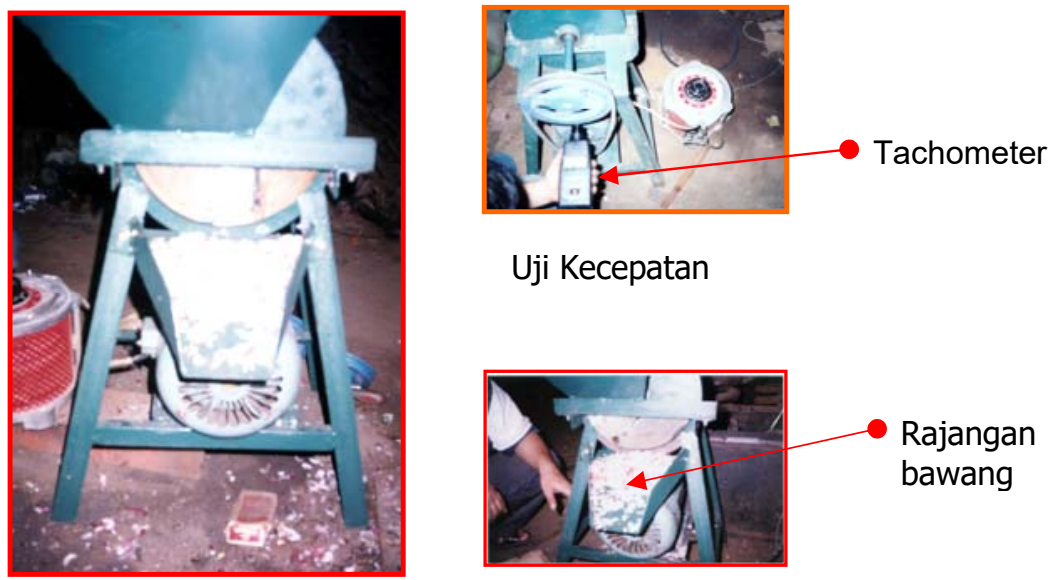

Uji Kecepatan

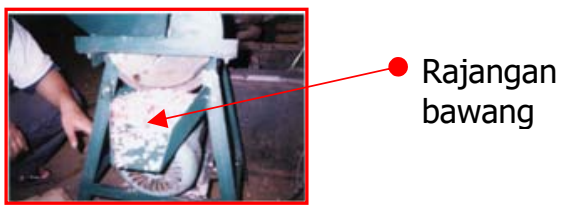

Gambar 14. Proses Ujicoba Unjuk Kerja TTG Mesin Perajang Bawang 
Tabel 1. Data Hasil Ujicoba/Pengujian TTG Mesin Perajang Bawang

\begin{tabular}{|c|c|c|c|}
\hline $\begin{array}{c}\text { Putaran } \\
\text { (Rpm) }\end{array}$ & $\begin{array}{c}\text { Kecepatan } \\
\text { potong } \\
\text { (m/det) }\end{array}$ & $\begin{array}{c}\text { Kapasitas } \\
\text { (Kg/menit) }\end{array}$ & $\begin{array}{c}\text { Tebal } \\
\text { Rajangan } \\
(\mathbf{m m})\end{array}$ \\
\hline 100 & 1,3 & 0,4 & 2 \\
\hline 200 & 2,6 & 0,5 & 2 \\
\hline 300 & 3,9 & 0,6 & 2 \\
\hline 400 & 5,2 & 0,7 & 1 \\
\hline 600 & 7,8 & 1,2 & 1 \\
\hline 700 & 9,1 & 1,2 & 1 \\
\hline 800 & 10,4 & 1,4 & $<1$ \\
\hline 900 & 11,7 & 1,4 & $<1$ \\
\hline
\end{tabular}

Dari hasil ujicoba yang dilakukan sebagaimana disajikan dalam Tabel 1, dengan variabel kecepatan piringan pemotong dengan jarak masing-masing $120^{\circ}+$ $15^{\circ}$, sudut kemiringan pisau $5^{\circ}$ diketahui hasil rajangan dengan kualitas dan kwuantitas optimal (ketebalan irisan $1 \mathrm{~mm}$, kapasitas irisan 1,2 kg/menit pada putaran piringan $600 \mathrm{rpm}$ dengan kecepatan potong 7,8 $\mathrm{m} /$ detik. Untuk kecepatan yang lebih tinggi dari $600 \mathrm{rpm}$ ternyata tidak dapat dihasilkan rajangan yang baik, sebab setelah kena rajangan pisau yang pertama dengan cepat bawang akan terkena pisau selanjutnya, sehingga terjadi pencacahan yang berulang. Sedangkan pada putaran $1000 \mathrm{rpm}$ dan seterusnya tidak dapat dilakukan pengamatan karena pisau potong mengalami getaran yang berlebih pada poros yang menyebabkan piringan pisau menjadi tidak stabil.

Perbandingan spesifikasi TTG Mesin Perajang Bawang dengan alat perajang bawang yang dipakai selama ini adalah seperti berikut:

Tabel 2. Perbandingan spesifikasi TTG Mesin Perajang bawang dari hasil penelitian dengan alat perajang manual yang dipakai sehari-hari

\begin{tabular}{|l|l|l|}
\hline \multicolumn{1}{|c|}{ Keterangan } & \multicolumn{1}{c|}{$\begin{array}{c}\text { TTG Mesin } \\
\text { Perajang Bawang }\end{array}$} & \multicolumn{1}{|c|}{$\begin{array}{c}\text { Alat Perajang } \\
\text { bawang manual }\end{array}$} \\
\hline Sumber tenaga & Motor listrik & Tangan \\
\hline Daya & $0,5 \mathrm{Hp}$ & - \\
\hline Jumlah pisau & $3 \mathrm{buah}$ & $3 \mathrm{buah}$ \\
\hline Diameter piringan & $250 \mathrm{~mm}$ & $10 \mathrm{~mm}$ \\
\hline Panjang pisau & $10 \mathrm{~cm}$ & $3 \mathrm{~cm}$ \\
\hline Sudut kemiringan pisau & $5^{\circ}$ & $8^{\circ}$ \\
\hline Putaran piringan & $600 \mathrm{rpm}$ & - \\
\hline Lebar corong/curah masuk & $14 \mathrm{~cm}$ & $5 \mathrm{~cm}$ \\
\hline Kemampuan curah & $15 \mathrm{buah}$ bawang & $3 \mathrm{buah}$ bawang \\
\hline Ketebalan irisan & $1 \mathrm{~mm}$ & $2-3 \mathrm{~mm}$ \\
\hline Kapasitas potong & $1,2 \mathrm{~kg} / \mathrm{menit}$ & $0,28 \mathrm{~kg} / \mathrm{menit}$ \\
\hline
\end{tabular}

Dari tabel di atas bisa dilihat kapasitas rajangan untuk TTG Mesin Perajang bawang yang dihasilkan dari penelitian ini sebesar $1,2 \mathrm{~kg} /$ menit, jauh lebih besar dibanding dengan kapasitas alat perajang bawang manual yang selama ini dipakai IKM. Kualitas bawang hasil rajangan dengan TTG ini ukurannya juga lebih baik dan seragam dibanding dengan hasil rajangan yang menggunakan alat manual sebelumnya. Hal ini berarti efektifitas dan efisiensi (produktivitas) yang merupakan target dari penelitian ini dapat tercapai, karena terbukti TTG yang dihasailkan dapat digunakan untuk melakukan perjangan bawang secara efektif dan efisien.

\section{KESIMPULAN}

Dari hasil ujicoba TTG Mesin Perajang bawang yang dihasilkan melalui kegiatan ini, dan analisis data hasil ujucoba unjuk kerjanya maka dapat disimpulkan bahwa :

1. Pelaksanaan program PPK berhasil merancang TTG Mesin Perajang bawang yang terbukti dapat digunakan secara efektif dan efisien sehingga betul-betul dapat digunakan untuk meningkatkan produktivitan IKM.

2. Spesifikasi TTG mesin perajang bawang yang dihasilkan melaui pelakanaan program PPK ini adalah : berat $14,8 \mathrm{~kg}$, motor $1 / 2 \mathrm{PK}$, dan kapasitas TTG $1,2 \mathrm{~kg}$ bawang irisan per menit. 
3. Kwulaitas hasil rajangan bawang yang diproses dengan menggunakan TTG ini jauh lebih baik dibanding dengan hasil rajangan yang dilakukan dengan menggunakan alat perajang manual yang dipakai IKM sebelumnya.

4. Kelebihan lain yang dimiliki TTG alat perajang bawang hasil penelitian ini yakni dapat menghasilkan rajangan bawang yang lebih rapi dan seragam dalam waktu singkat, dan hampir tidak ada yang rusak/hancur.

5. Dengan menggunakan TTG hasil rancangan tim pelaksana PPK ini berarti IKM tidak hanya dapat meningkatkan kapasitas produksinya, tetapi juga dapat meningkatkan kualitas pelayanan kepada customer-nya karena dapat digunakan untuk memenuhi order tepat pada waktunya.

\section{REFERENSI}

[1] Ahmadi Fuad (2001), Karakteristik Teknologi Tepat Guna Dalam IndustriSkala Usaha Kecil dan Menengah di Jawa Timur. Makalah yangDisampaikan dalam rangka pelatihan produktivitas usaha kecil diUnesa.Tanggal 26 Juli tahun 2001.

[2] Haryono dkk. (1999). Buku Panduan Materi Kuliah Kewira-usahaan. Unipres UNESA Surabaya

[3] John E Biegel (1998). Pengendalian Produksi, Suatu Pendekatan Kuantitatif . Terjemahan. Tarsito Bandung

[4] Nyoman Sutantra I (2001). Produktivitas Sistem Produksi dan Teknologi. Makalah yang disampaikan dalam rangka pelatihan produktivitas usaha kecil di Unesa.Tanggal 26 Juli tahun 2001.

[5] Sularso dan Kiyokatsu Suga (1983). Dasar Perencanaan dan Pemilihan Elemen Mesin. Cetakan Ke epmat, Jakarta: PT Pradnya Paramita, Jakarta.

[6] Sutiono (2001). Produktivitas UKM di Jawa Timur. Makalah yang disampaikan dalam rangka pelatihan produktivitas usaha kecil di Unesa.Tanggal 26 Juli tahun 2001.

[7] V Dobrovolsky. Machine Elements, Foregn Language Publishing House, Moscow

[8] Wayan Barata (1983). Elemen Mesin I,II,III Teknik Mesin FT ITS. 